\title{
Syntactic Requirements on Adjuncts*
}

\author{
Werner Frey \\ Zentrum für Allgemeine Sprachwissenschaft, Berlin \\ frey@zas.gwz-berlin.de
}

\begin{abstract}
The paper proposes structural constraints for different adjunct classes in German and English. Approaches in which syntax has only the task to provide adjunct positions and in which principles of scope are supposed to explain the distribution of adjuncts are rejected as incomplete. The syntactic requirements are not as rigid as other approaches require, such that there is just one possible position for a given adjunct. Rather the syntactic constraints may be fulfilled in different positions.
\end{abstract}

\section{On base positions in German}

It is well known that in the middle field of a German clause the constituents may appear in different order. Nevertheless most syntacticians working on German agree that verbal arguments have base positions. Other serializations are derived from the base serialization by scrambling. Some of the data which have been used to show that there are base positions of arguments are the following:

(I) Existentially interpreted wh-phrases

Existentially interpreted wh-phrases (nonspecific reading) resist scrambling. Therefore they constitute a good means to determine base positions:

(1) a. weil jemand was lesen will

because someone something read want

'because someone wants to read something'

b. *weil was jemand lesen will

(II) Eocus projection

It is possible in German that a clause may have a wide focus reading if the constituent adjacent to the predicate receives nuclear stress. It has been shown that in order for this to happen the stressed constituent has to be verb adjacent in the base serialization (cf. Höhle (1982), Haider (1993)).

(2) a. Gestern hat ein Kollege einer Dame ein GeMÄLde gezeigt (wide focus possible) yesterday has a colleague a woman (Dat) a painting shown

'Yesterday a colleague showed a woman a painting'

b. Gestern hat ein Kollege ein Gemälde ${ }_{1}$ einer DAme $t_{1}$ gezeigt (only narrow focus)

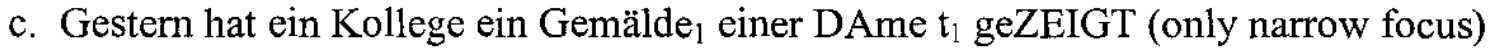

\footnotetext{
* I wish to thank Chris Wilder for very helpful discussions. This paper develops further joint work with Karin Pittner; cf. Frey \& Pittner (1998, 1999).
} 
(5) weil (anscheinend) Hans (anscheinend) Maria (anscheinend) einladen wird because (apparently) H. (apparently) $M . \quad$ (apparently) invite will

Data like this have led different authors to claim that SADJs can be base generated everywhere in the middle field (e.g. Hetland (1992), Laenzlinger (1998)).

A closer look however reveals that there are severe restrictions for the relative position between SADJs and other constituents:

(6) a. *weil wer vermutlich das Buch entliehen hat because someone probably the book borrowed has

b. weil vermutlich wer das Buch entliehen hat

c. *Hans ist wegen was leider böse Hans is of something unfortunately angry

d. Hans ist leider wegen was böse

In Frey (2000) it is argued that all phrases preceeding SADJs in the middle field are topics in the aboutness-sense 1 . The phrases are moved to these topic positions. Wh-indefinites can not be moved. Therefore the sentences $(6 \mathrm{a}, \mathrm{c})$ are ungrammatical.

There is another restriction for the distribution of SADJs. It is possible to posit a complex verbal projection in the prefield of a German clause. Interestingly such a constituent can not contain a SADJ:

(7) *glücklicherweise viel gelacht wird in diesem Land

luckily a lot laughed is in this country

'Luckily people laugh a lot in this country'

This can be related to the following fact. A SADJ has necessarily scope over the temporal information of the clause:

(8) *Gestern hat Otto bedauerlicherweise gewonnen, aber heute bin ich froh darüber Yesterday has $O$. unfortunately won, but today am I glad about it

This sentence can not express that yesterday the speaker regretted that Otto has won, but today he is glad about it. (8) is contradictory because the regret is not temporally restricted.

1 This holds with two exceptions, the first being irrelevant for the current discussion. First, all kind of elements which are pronounced with the special pronunciation called I-contour can be placed right after the Cprojection and before the topics:

(i) Da LEsen $_{1}$ Otto leider dieses Buch NICHT $_{1}$ möchte

because read $O$. unfortunately this book not wants

"because $O$. unfortuantely does not want to read this book"

Second, discourse-oriented adjuncts like 'offen gestanden' (frankly) or 'kurz gesagt' (briefly) preceed SADJs:

(ii) a. weil offen gestanden leider während deines Vortags jemand eingeschlafen ist because frankly unfortunately during the talk someone fallen asleep is

b. *weil leider offen gestanden während deines Vortags jemand eingeschlafen ist

The same is true for English:

(iii)a. Paul frankly will unfortunately have to leave the company

b. *Paul unfortunately will frankly have to leave the company

These adjuncts modify the implicit assertion operator of the sentence. Therefore they take the sentence's maximal proposition in their scope. 
Scope relations in semantics correspond to c-command relations in syntax. The finite verb is the representative of the temporal information of the clause. The semantic relation between a SADJ and the temporal information therefore is reflected by the requirement that a SADJ has to c-command the finite verb. This explains the ungrammaticallity of (7). The SADJ in (7) being part of a complex constituent in the prefield does not c-command the finite verb of the clause.

Our observations about SADJs in German can be captured by the following constraint:

(9) $\underline{\text { SADJS }}$

The base position of a SADJ has to c-command

(i) the base positions of all arguments and of all other adjuncts (except of discourseoriented adjuncts) and

(ii) the base position of the finite verbal form.

It can easily be shown that in German the conditions in (9) hold for all the three subtypes of SADJs mentioned at the beginning of this section.

There are order restrictions between the subtypes of SADJs (cf. e.g. Cinque (1997), Ernst (to appear)). Now, these restrictions can be justified in purely semantic terms (cf. e.g. Ernst (to appear)). It is questionable whether these restrictions have any syntactic encoding. To my mind, they should accordingly be captured in the semantic component of the grammar and not in the syntactic part. ${ }^{2}$

We can check now whether a condition like (9) also holds for English. We find the following distribution of a SADJ:

(10) a. (Unfortunately) She (unfortunately) will (unfortunately) be (*unfortunately) talking (*unfortunately) about this subject (*unfortunately)

b. (Unfortunately) She (unfortunately) talked (*unfortunately) about this subject (*unfortunately)

Nowadays nearly every syntactician assumes that the subject of an English clause is moved to the surface position from its base position inside the verbal projection. Furthermore most syntacticians assume that a finite auxiliary in English is base generated in a V-position and moved to the I-position ${ }^{3}$. A finite main verb, however, is not moved to I.

(11) a. [IP She ${ }_{1}$ will $_{2}\left[{ }_{v P} t_{2}\left[v p\right.\right.$ be [vP $t_{1}$ talking about this subject]]]]

b. [IP She, [vP $t_{1}$ talked about this subject]]

Finally we adopt the prohibition against right adjunction (e.g. Larson (1988), Haider (1993), Kayne (1994)). We can indicate these three assumptions for (10) as follows:

$(10)^{\prime}$ a. (Unfortunately) [IP $\mathrm{She}_{1}$ (unfortunately) will 2 (unfortunately) ${ }_{\mathrm{vp}} \mathrm{t}_{2}$ be (*unfortunately) [ $\mathrm{vP}_{\mathrm{P}} \mathrm{t}_{1}$ talking (*unfortunately) about this subject (*unfortunately)]]]

2 In section 3 it is, with regard to event-internal adjuncts, shown that the syntactic component does not differentiate between the subtypes of an adjunct class.

3 Ernst (1991) gives a scope argument for this assumption. In the following sentence clearly has scope over can. However clearly can not have scope over already.

(i) Gary already can 1 clearly $t_{1}$ lift 100 pounds

These facts find an explanation if the base position of can in (i) is to the right of clearly. Clearly c-commands the trace of the auxiliary. But it does not c-command already. 
b. (Unfortunately) [ip $\mathrm{She}_{1}$ (unfortunately) [vp $\mathrm{t}_{1}$ talked (*unfortunately) about this subject (*unfortunately)]]

The conditions in (9) explain the distribution of the SADJ in (10). All occurrences of the $\mathrm{SADJ}$ in front of the main verb fulfil condition (9i). In (10b) these occurrences also ccommand the finite verb, i.e. they fulfil (9ii). However only the first three occurrences of 'unfortunately' in (10a) c-command the base position of the finite verb. ${ }^{4}$ The occurrence of the SADJ right after the main verb in (10a) and (b) neither fulfils condition (i) nor condition (ii). Due to the binary right-branching structure of the English clause (Haider (1992), Kayne (1994)) the SADJ does neither c-command the subject nor the finite verb. The sentence final occurrence of the SADJ will be discussed in section 8 . Note that according to (9) all the grammatical positions of the SADJ in (10) are base positions of the adjunct.

According to (9i) a SADJ has not only to c-command the base positions of the arguments but also the base positions of other adjuncts. This requirement captures examples like the following:

(12) a. John fortunately will therefore have read the book

b. *John therefore will fortunately have read the book

In (12) the adjuncts are in base positions because there is no scrambling in English. The positions which the causal adjunct and the SADJ occupy in (12b) are in principle possible for these adjuncts. But if they occur together the SADJ has to preceed.

Let us next have a quick look at frame adjuncts. Like SADJs they are related to propositions. Frame-setting adjuncts restrict the claim which the speaker makes by his assertion. One of the examples of Maienborn (1998) is the following:

(13) In Deutschland bin ich weltberühmt

(H. Juhnke)

In Germany am I world-famous

In this sentence the claim for the truth of the proposition "I am world-famous" is restricted to a certain spatial region.

Frame adjuncts are often considered as topics (e.g. Chafe (1976)). But it is clear that they have to be differentiated from aboutness-topics (cf. Jacobs (1999)). In fact if they can not be an aboutness-topic due to non-referentiality they have to follow SADJs, i.e. they can not be in the topic field of the German middle field (Frey (2000)):

(14) a. *Otto ist in keinem Land erstaunlicherweise sehr berühmt

$O$. is in no country surprisingly very famous

b. Otto ist erstaunlicherweise in keinem Land sehr berühmt

(14b) shows that the base position of a frame adjunct is below of an SADJ. If a frame adjunct is referential it may be positioned in the topic field above the SADJs and become an aboutness-topic thereby:

(15) Otto ist in Deutschland erstaunlicherweise sehr berühmt

O. is in Germany surprisingly very famous

4 In $d o$-insertion contexts the auxiliary is base generated in I. Thus in such a sentence a SADJ cannot occur after the auxiliary:

(i) *John did not probably miss the lecture 
Above we observed that an SADJ is outside the scope of the temporal information of the clause. What about frame adjuncts in this respect? The following example shows that a frame adjunct can be in the scope of a (frame-setting) tense operator:

(16) Im 16. Jahrhundert haben in Deutschland Mönche viel Bier getrunken In $16^{\text {th }}$ century have in Germany monks a lot of beer drunk

The sentence refers to the monks who lived in the region of Germany which it had in the $16^{\text {th }}$ century. It does not refer to the monks who lived in the region of Germany which it has nowadays.

Because frame adjuncts do not have to have scope over tense they do not have to ccommand the finite verb form. Therefore, in contrast to a SADJ (cf. (7)), a frame adjunct can appear inside a verbal projection in the prefield of a German clause:

(17) in Deutschland viel Bier getrunken wurde bedauerlicherweise damals

in Germany a lot of beer drunk was unfortunately at that time

'In Germany people unfortunately drank a lot of beer at that time'

The following example shows that a frame adjunct is base generated higher than the arguments:

(18) *daß wer in diesem Dorf weltberühmt ist

that someone in this village world-famous is

Similarly it can be shown that a frame adjunct is generated higher than the adjuncts discussed in the next section.

\section{Event-related adjuncts and event-internal adjuncts}

With regard to their syntactic behaviour many authors put temporal, causal, local, purpose and instrumental PP-adjuncts together into one class, e.g. Cinque (1997), Ernst (to appear), Haider (1999). According to Ernst (to appear) for example, they are not ordered with respect to each other because they are without scope requirements. According to Cinque (1997), they are unordered because they do not occupy the specifier position of distinct functional projections in contrast to AdvPs proper. Neeleman (1994) and Zwart (1993) state that temporal and locative adjuncts may adjoin to all maximal projections within the clause. Usually these adjuncts are considered to be of the same semantic type. It is assumed that they all are predicated on the event-variable which is part of the argument structure of the verb.

It is certainly true that these adjuncts can be ordered rather freely in certain environments:

(19) a. Er wird am Freitag in Hamburg eine Rede halten

b. Er wird in Hamburg am Freitag eine Rede halten

c. He will give a talk on Friday in Hamburg

d. He will give a talk in Hamburg on Friday

However it seems to be wrong to conclude from this that these adjuncts are not ordered. The following German data show that e.g. temporal and local adjuncts behave differently with respect to the diagnostics for base positions: 
(20) a. daß wann wer das Zimmer aufräumen wird that sometimes someone the room tidy up will

b. *daß wer wann das Zimmer aufräumen wird

c. weil wer wo das Buch verloren hat because someone somewhere the book lost has

d. *weil wo wer das Buch verloren hat

Test (I) of section 1 shows that a temporal adjunct is base generated higher than the base position of the subject of a transitive verb (cf. $(20 a, b)$ ). In contrast $(20 \mathrm{c}, \mathrm{d})$ show that a locative adjunct is base generated below the subject position.

That temporals and locatives have different base positions can also be shown by a direct comparison of the two adjuncts:

(21) a. Hans solite wann wo darüber vortragen

H. should sometimes somewhere about that talk

'H. should talk about that somewhere sometimes'

b. *Hans sollte wo wann darüber vortragen

These findings are confirmed by the application of test (III) of section 1:

(22) a. WEIL mindestens einer an fast jedem Tag eine Wahlrede halten wird - ambiguous because at least one on almost every day an election speech make will 'because at least one person will make an election speech almost every day'

b. WEIL mindestens einer an fast jedem Ort eine Wahlrede halten wird - only: $\exists \forall$ because at least one at almost every place an election speech make will

In (22a) the subject preceeds the temporal adjunct. The sentence is ambiguous. According to the scope principle in (3) the reading with wide scope of the temporal adjunct is possible because the base position of the subject is in its c-command domain. In sentence (22b) the subject preceeds a locative adjunct. This sentence has only the reading which corresponds to the surface order of the quantifiers. This means that the locative is base generated below the subject.

Because the opinion is widespread that temporals and locatives behave alike, I would like to give further evidence to the contrary. Let us look at bare plurals. It is well know that the interpretation of a bare plural depends on the position of the bare plural in the clause (cf. Diesing (1992)):

(23) a. Heute hat eine Frau Kindern zwei Bonbons gegeben

Today has a woman children two sweets given

'Today a woman gave sweets to some children'

b. Heute hat Kindern eine Frau zwei Bonbons gegeben

'Today children got two sweets from a woman'

The bare plural Kindern in (23a) can have an existential interpretation. (A generic interpretation is possible too. The translation given therefore corresponds only to one of the readings.) In contrast the bare plural in (23b) can only be interpreted generically.

In (23a) the bare plural object is in its base position, in (23b) it has been scrambled in front of the subject. The difference in interpretation between (23a) and (b) is captured by the following condition: 
(24) The domain of existential closure is restricted by the base position of the highest argument. Indefinite NPs outside this domain have to be interpreted as strong, e.g. as generic. $^{5}$

The following examples differ in the position of the bare plural object relative to a locative and to a temporal adjunct respectively:

(25) a. Die Polizei hat vor zwei Tagen im Universitätspark Linguisten befragt The police has two days ago in the university park linguists questioned 'Two days ago the police questioned some linguists in the university park'

b. Die Polizei hat vor zwei Tagen Linguisten im Universitätspark befragt 'Two days ago the police questioned some linguists in the university park'

c. Die Polizei hat Linguisten vor zwei Tagen im Universitätspark befragt 'Two days ago (quasi-)all linguists got questioned by the police in the university park'

A bare plural object which occurs after or in front of a locative adjunct can have an existential reading, cf. $(25 \mathrm{a}, \mathrm{b})$. In contrast, a bare plural in front of a temporal adjunct is necessarily interpretated generically, cf. (25c).

These observations confirm that temporal adjuncts belong to a different class than local adjuncts. More precisely they confirm that the base position of a temporal adjunct is higher and that the base position of a locative is lower than the base position of the highest argument.

Having said that the base position of a locative is below the subject of a transitve verb we should determine its position relative to the object:

(26) a. Peter hat heute im Hörsaal wen beleidigt

$P$. has today in the lecture hall someone offended

"Peter offended someone in the lecture hall today"

b. ??Peter hat heute wen im Hörsaal beleidigt

c. Er HAT in fast jedem Park mindestens eine Dame geküßt (unambiguous) He has in almost every park at least one woman kissed

d. Er HAT fast jede Dame in mindestens einem Park geküßt (ambiguous) He has almost every woman in at least one park kissed

These data show that locatives are generated above the base position of the object.

With the same test it can be shown that, with respect to the arguments, instrumentals are positioned like locatives: ${ }^{6}$

5 The constraint allows scrambling of an existential indefinite below the subject (contra de Hoop (1992)):

(i) Otto will heute abend Dias einer Freundin zeigen

O. wants tonight slides a friend show

'Tonight $\mathrm{O}$. want to show a friend some slides'

6 For the following examples the reader is asked to abstract from the independent tendency to let a heavier constituent (like the PP wh-indefinite) follow a lighter element (like the NP-indefinite) in the German middle field.

We can also apply test (II):

(i) Er hat mit dem Messer die DOse geöffnet (wide focus possible)

He has with the knife the tin opened.

The fact that the sentence allows the wide focus reading indicates that the object is base-generated next to the verb. 
(27) a. weil wer mit was den Tisch beschädigt hat because someone with something the table damaged has 'because someone damaged the table with something'

b. *weil mit was wer den Tisch beschädigt hat

c. da Otto mit was wen am Kopf getroffen hat since $O$. with something someone on the head hit has

d. ??da Otto wen mit was am Kopf getroffen hat

Let us now see how these adjuncts behave with respect to each other:

(28) a. Er HAT mit mindestens einer Maschine in fast jedem Haus gearbeitet - only: $\exists \forall$ He has with at least one machine in almost every house worked

b. Er HAT in mindestens einem Haus mit fast jeder Maschine gearbeitet - only: $\exists \forall$

(29) a. Er hat gerade wo mit was viel Geld verdient He (has) right now somewhere with something much money earned

b. Er hat gerade mit was wo viel Geld verdient He (has) right now with something somewhere much money earned

(28) shows that both orders of a quantified locative and a quantified instrumental adjunct are unambiguous. (29) shows that both orders of a locative wh-indefinite and of an instrumental wh-indefinite are grammatical. Thus the data show that instrumentals and locatives are unordered with respect to each other. Therefore in Frey \& Pittner (1998) it is proposed that they belong to the same class of adjuncts. With the same tests it can be shown that further adjunct types belong to this class, e.g. benefactives. The members of the class are called event-internal adjuncts and they have to fulfil the following requirement:

(30) Event-internal adjuncts, type I (e.g. locatives, instrumentals, benefactives)

The base position of an event-internal adjunct is minimally c-commanded by the base position of the highest argument, i.e. there is, modulo elements of the same class, no other element whose base position c-commands the event-internal adjunct.

(30) is the only requirement which is imposed on these adjuncts by syntax, i.e. the syntactic component does not differentiate between the members of the class. ${ }^{7}$

As we have seen temporal adjuncts belong to another class. The members of this class, to which, as can be shown, also e.g. causals belong, have to fulfil the following condition:

(31) Event-related adjuncts (e.g. temporals, causals)

The base position of an event-related adjunct c-commands the base position of the highest argument and the base positions of event-internal adjuncts.

It could again be shown, in a way analogous to $(28) /(29)$, that syntax does not order the subtypes of the class with respect to each other.

The conditions (30) and (31) do not only explain the contrasts observed in (20)-(22) and in (25) they also account for the following facts:

7 The condition refers to the highest argument. The reason is that in German for some verbs it is not the subject which is realized most prominently but another argument. (45) in section 4 gives an example for such a verb. 
(32) a. Im Garten einen Artikel lesen will Otto In the garden an article read wants $O$.

'Otto wants to read an article in the garden'

b. ??Am Abend einen Artikel lesen will Otto

In the evening an article read wants $O$.

It is possible to move a complex verbal projection to the prefield of a German clause. In (32a) the locative adjunct is part of such a verbal projection. According to (30) this complex phrase does not have to contain the base position of the subject. The situation is different in (32b). According to (31) a temporal adjunct has to c-command the base position of the subject. Therefore the complex verbal projection in (32b) contains a trace of the subject. However the subject trace is unbound which results in the degraded status of grammaticality.

Another observation can also be explained by the conditions (30) and (31). The filling of the prefield with a temporal adjunct in German results in a unmarked strucure. In contrast the filling with a locative yields a marked strukture. The locative is highlighted with regard to information structure:

(33) a. Vor einer Woche hat Hans das Problem gelöst (unmarked)

One week ago has $H$. the problem solved

b. In einem Flugzeug hat Hans das Problem gelöst (marked)

In an airplane has $H$. the problem solved

According to (31) a temporal can be base generated in the prefield. According to (30) a locative has to be moved to this position. Movement to the prefield is not for checking of grammatical features however, rather it is for pragmatic needs.

Let us now look at some English data containig adjuncts of the two classes:

(34) a. On Ben ${ }_{1}$ 's birthday he 1 took it easy

b. For Mary ${ }_{1}$ 's valour she $e_{1}$ was awarded a purple heart

c. ?*In Ben ${ }_{1}$ 's office he $e_{1}$ lay on his desk

d. *With Mary ${ }_{1}$ 's computer she $e_{1}$ began to write a book of poetry

Suppose the conditions (30) and (31) also hold for English. In (34a) and (b) we have a temporal and causal adjunct respectively. For these adjuncts condition (31) is relevant. This condition allows the base generation of the adjunct phrases in the sentence initial position. In (34c) and (d), however, a locative and an instrumental adjunct are sentence initial. These adjuncts are members of the class of event-internal adjuncts and they have to obey condition (30). Therefore the adjuncts in (34c) and (d) have arrived their surface position by movement. For (34c) for example we have a structure like the following:

$(34)^{\prime}$ c. $\left[\text { In Ben }{ }_{1} \text { 's office }\right]_{2}$ he 1 lay on his desk $t_{2}$

After reconstruction of the moved phrase we get a principle $\mathrm{C}$ violation. The same reasoning applies to $(34 \mathrm{~d})$. Since there is no reconstruction in $(34 \mathrm{a}, \mathrm{b})$, those sentences are grammatical.

There are further differences between the members of the different adjunct classes (30) and (31) in English:

(35) a. John 1 ((?)by then) will (by then) have ((?)by then) $t_{1}$ read the book

b. John $\left({ }^{*}\right.$ here $)$ will $\left({ }^{*}\right.$ here $)$ be $\left({ }^{*}\right.$ here $) t_{1}$ reading this book 
In formal/written registers even some heavier adjuncts are possible in the AuxRange. Ernst (to appear) gives the following examples and judgements:

(36) a. They $y_{1}$ had two weeks earlier been $t_{1}$ fixing the bookshelf

b. *They ${ }_{1}$ had with a hammer been $\mathrm{t}_{1}$ fixing the bookshelf

c. ${ }^{*}$ They $_{1}$ had for Lisa been $t_{1}$ fixing the bookshelf

Given the condition in (30) and (31), the data in (35) and (36) can be explained. The temporal adjunct in (36a) fulfils condition (31). It does c-command the base position of the subject. So the sentence is fine. The adjuncts in $(36 \mathrm{~b}, \mathrm{c})$ however would have to fulfil condition (30), i.e. they should be minimally c-commanded by the base position of the subject. Since this is not the case, the sentences are bad.

The same kind of reasoning explains the distributions of the adjuncts in (35). In all of the positions indicated, by then fulfils condition (31). In contrast in none of its positions does here fulfil condition (30).

In principle it is possible in English to have an adjunct between the verb and a prepositional object:

(37) John has spoken carefully about the subject

We will discuss such examples not before section 6 . But right now we have to rule out the following ungrammatical sentences 8 :

(38) a. John $n_{1}$ will have $t_{1}$ spoken (*by then) about the subject

b. John $n_{1}$ will $t_{1}$ speak (?? here) about the subject

Since Larson (1988) most syntacticians assume a binary right-branching structure for English. This leads to a so-called Larsonian shell structure. For a verb with two objects the shell structure has roughly the following form?

$$
\left[{ }_{v P} N P V_{1}\left[v P X P\left[v^{\prime} t_{1} X P\right]\right]\right]
$$

The theta-licencing of the arguments is done successively by the verb. The subject then moves further to a functional projection to check grammatical features.

Due to binary branching, the vPs of the sentences in (38) are as follows ${ }^{10}$ :

$*\left[{ }_{v P}\right.$ John speak 1 [vP by then/here $\left[\mathrm{v}^{\prime} \mathrm{t}_{1}\right.$ about the problem $\left.\left.]\right]\right]$

Both kinds of adjuncts are not possible below the verb, but for different reasons. The temporal adjunct is not possible because it does not c-command the subject thereby violating condition (31). The locative is not possible because it is not minimally c-commanded by the subject.

8 If an event-internal or event-external adjunct occurs between the verb and an object, it can be shown that the object is extraposed:

(i) a. John will speak here to his mother

b. *Who 1 will John speak here to $t_{1}$

The freezing effect in (ib) is due to the fact that the prepositional object is not in its base position.

9 Chomsky (1995) introduced $v$ to which the verb is adjoined. $v$ is supposed to assign the agent theta role.

10 For the sake of concreteness the adjuncts are assigned to the spec position of VP. It is however irrelevant for our question whether the adjuncts are adjoined to VP or whether they are in its spec position. 
The interference of the verb violates condition (30). Note that the higher position of the verb is a base position as well as the lower one. Both positions are involved in theta licencing.

In addition to $(35 \mathrm{~b})$ we also have to rule out the following structure:

(41) $* \mathrm{John}_{1}$ will be $\left[{ }_{\mathrm{vP}} \mathrm{t}_{1}\right.$ here reading this book]

Due to the binary branching requirement this structure simply can not arise. In order to thetalicence the subject, the verb has to move to the left of the adjunct yielding a structure like $(38 b)$.

\section{Mental-attitude adjuncts}

There is an interesting difference in the interpretation of the following English and German sentences:

(42) a. that Peter deliberately was examined by the doctor

b. daß Peter bereitwillig von dem Arzt untersucht wurde

In sentence (42a) the mental-attitude adjunct 'deliberately' relates to 'Peter'. However in the German translation in (42b) the adjunct relates necessarily to 'the doctor'.

Furthermore, as is well known, if in English the adjunct is positioned after the main verb, the interpretation changes compared to (42a):

(43) that Peter was examined deliberately by the doctor

In (43) 'deliberately' relates to 'the doctor' as in the German example.

Let us first apply a test to determine the base position of the German mental-attitude adjuncts:

(44) a. da wer bereitwillig den Auftrag übernahm since someone deliberately the task took on

b. *da der Knabe was bereitwillig vorgesungen hat since the boy something deliberately sung has

c. da der Knabe bereitwillig was vorgesungen hat

These data seem to show that German mental-attitude adjuncts are base generated below the subject and above the object. A closer look however reveals that they do not relate to the subject per se but to the highest ranked argument of the predicate. In German in most cases this is the subject but it need not be. It can be shown that, in the following sentence, the dative is base generated higher than the nominative:

(45) weil einem Bekannten eine wichtige Vorstellung entgangen ist

because a friend (Dat) an important performance lost is

'because a friend missed an important performance'

It can be shown that in a construction like that a mental-attitude adjunct is base generated between the dative and the nominative: 
(46) weil wem versehentlich was entgangen ist because someone (Dat) inadvertently something lost is

Therefore the condition for mental-attitude adjuncts seems to be that its base position is minimally c-commanded by the base position of the highest ranked argument.

The English example (42a) shows that this can not be quite right. In (42a) the mentalattitude adjunct relates to the subject of a passive. Thus the adjunct does not have to relate to a base position. Rather the condition for mental-attitude adjuncts is the following:

(47) Event-internal adjuncts, type II (e.g. mental-attitude adjuncts)

The base position of a mental-attitude adjunct is c-commanded by a highest ranked argument inside the extended projection of the main predicate. Semantically a mentalattitude adjunct relates to the closest c-commanding highest ranked argument.

Let us now try to explain the contrast in interpretation between (42a) and (b). We expect that the difference is not due to a different behaviour of the adjuncts in the two languages but rather due to indepedently established structural differences.

Two differences are the following. Most prominently Haider (1993) argues that the two languages differ in the position of the subject. And furthermore, connected to the first point, he argues that in English an auxiliary heads its own projection whereas in German it constitutes a verbal complex with the main verb. One of the arguments for different subject positions is the fact that a German subject clause allows extraction of a constituent whereas an English one does not:

(48) a. Mit wem 1 würde [ $t_{1}$ Schach spielen zu dürfen] dich sehr freuen?

b. ${ }^{*} \mathrm{Who}_{1}$ would [to play chess with $\mathrm{t}_{1}$ ] have pleased you?

Haider (1993) concludes that in contrast to English the subject of a German clause remains in the licencing domain of the main predicate.

Among the arguments that an auxiliary and a main verb constitute a verbal complex in German are the observations that they may be moved together to the prefield (cf. (49a)) and that nothing may intervene between them (cf.(49b)):

a. [Gelesen haben] sollte jeder diesen Artikel Read have should everyone this article 'Everyone should have read this article'

b. *da dieser Artikel von jedem gelesen bald wird since this article by everyone read soon will-be

Applied to (42), these two differences between English and German imply that in (42a) the passive subject and the adjunct are part of the projection of the auxiliary whereas in (42b) both are part of the projection of the verbal complex.

Next we have to look at the argument structure of a passive predicate. The agent can be left unrealized or can be realized by a $b y$-phrase. The $b y$-phrase has properties of an adjunct. Corresponding to that it can be shown that the agent is present in the structure even if there is no $b y$-phrase present. Therefore the agent of a passive is called an implicit argument.

(50) a. The ship was sunk in order to get the insurance

b. Briefe wurden einander geschrieben Letters were to each other written 
In (50a) the implicit argument acts as an controler, in (50b) it is the binder of the reciprocal. Roberts (1987) takes the passive morphology on the verb as the syntactic representation of the implicit argument.

The implicit argument of a passive is accessible for an adjunct in the domain of the main predicate. First the agent is present in the syntactic structure. Second according to the definition of c-command in Chomsky (1981) a head c-commands all elements within its projection. Therefore the implicit argument, whose representative is the verb, c-commands all constituents within the verbal projection.

In German a mental-attitude adjunct is base generated higher than the subject of a passive:
a. weil absichtlich wer heruntergestoßen wurde because deliberately someone pushed-down was
b. *weil wer absichtlich heruntergestoßen wurde

In German there is no movement of the 'deep object' in passives. The subject of a passive has the same base position as the corresponding object of the active. The mental-attitude adjunct in (51a) is base generated above the passive subject as it would be base genereted above the corresponding object of the active.

We can now explain the differences observed in (42). The subject of (42a) does not belong to the projection of the main verb, rather it is part of the projection of the auxiliary. The highest ranked argument inside this projection c-commanding the adjunct is the surface subject. Therefore the adjunct relates to this constituent, i.e. to Peter. The situation is different in (42b). The German auxiliary does not head its own projection rather it forms a verbal complex with the main verb. The whole middle field is dominated by a projection of the verbal complex. The adjunct is a constituent within this projection. The verbal complex ccommands the adjunct. Therefore the implicit argument, which is represented by the verbal form, c-commands the adjunct. The implicit argument is the highest ranked argument inside the verbal projection. That the subject of $(42 \mathrm{~b}) \mathrm{c}$-commands the adjunct on the surface, is only an effect of scrambling of the subject, as (51) shows. Therefore the adjunct relates to the implicit argument in the German example.

If in English the adjunct is positioned as in (43), we have the same situation as in the German example (42b). The adjunct is part of the projection of the main verb. It is ccommanded by the verb. The verb is the representative of the agent. Therefore the adjunct relates to the agent.

The example (42a) shows that a mental-attitude adjunct does not have to relate to a 'deep subject'. Rather it relates to the nearest c-commanding highest ranked argument on the surface. The fact that mental adjuncts are not licenced by base configurations but by surface structures is also illustrated by the following data:

(52) Terry (intentionally) has (intentionally) been (intentionally) reading Hamlet

(52) shows that mental-attitude adjuncts have a wide distribution in the Aux-Range of English. In all its position in (52) the mental adjunct fulfils requirement (47).

\section{On the sentence initial occurence of adjuncts}

In this section it will be discussed whether sentence initial adjuncts are base gencratcd in this position. 
Let us start with subject-oriented adjuncts like rudely or cleverly. Like many other adjunct types, they do not only occur sentence internally but may also introduce an English clause:

(53) a. John cleverly made no reply

b. Cleverly John made no reply

With these adjuncts the speaker evaluates a proposition with respect to the subject of the clause: It was clever by John that he made no reply.

Subject-oriented adjuncts differ from the mental-attitude adjuncts considered in the last section not only in their semantics but also in their syntactic behaviour. In German for example a mental-attitude adjunct may appear as part of a complex verbal projection in the prefield. In the same position a subject-oriented adjunct is less good:

(54) a. absichtlich das Fenster zerstört hat Otto deliberately the window destroyed has Otto

' $O$. deliberately destroyed the window'

b. ??netterweise das Fenster repariert hat Otto nicely the window repaired has $O$.

'It was nice of $O$. to repair the window'

This difference follows if we realize that subject-oriented adjuncts share one important property with the class of SADJs. Like the SADJ characterized in (9) they always have scope over the temporal setting of the sentence, i.e. they have to c-command the base position of the finite verb. Mental-attitude adjuncts as characterized in (47) do not have to c-command the finite verb.

In fact, subject-oriented adjuncts are usually classified as SADJs in the literature. However, the fact that, by using a subject-oriented adjunct, the evaluation by the speaker is attributed on the subject constitutes an important semantic difference to other SADJs. Is the difference reflected in syntax? There is evidence for this. Compare the following sentences:

a. weil erfreulicherweise wer antwortete because fortunately soemeone (or other) answered

b. *weil intelligenterweise wer antwortete because wisely soemeone (or other) answered

c. ${ }^{*}$ weil wer intelligenterweise antwortete

d. weil Hans intelligenterweise antwortete

In (55a) the SADJ behaves as characterized in section 2 . However it can not be replaced by a subject-oriented adjunct, as (55b) shows. (55b) indicates that a subject-oriented adjunct can not be generated above the position of the subject. It has to be c-commanded by the subject at some level. Thereby it is structurally reflected that a subject-oriented adjunct is semantically attributed on the subject. (55c) shows that the base position of a subject-oriented adjunct can not be below the subject. (55d) is fine because the subject has been moved.

Let us now look at an interesting syntactic difference between subject-oriented adjuncts and other SADJs at the beginning of an English clause. Consider the following sentences: 
(56) a. *Who, do you think that $\mathrm{t}_{1}$ made no reply

b. Who ${ }_{1}$ do you think that unfortunately/apparently $t_{1}$ made no reply

c. ${ }^{*} \mathrm{Who}_{1}$ do you think that stupidly $\mathrm{t}_{1}$ made no reply

In (56) we have subject movement out of an embedded that-clause. (56a) shows the standard that-trace effect. Interestingly, an evaluative or an evidential cancels the that-trace effect, as (56b) shows. Subject movement is possible across such SADJs. But it is not possible across a subject-oriented adjunct, cf. (56c). A subject-oriented adjunct is not able to cancel the thattrace effect. These facts are puzzling because the different adjuncts have the same distribution in English. Both for example can appear at the beginning of the clause.

Browning (1996) and Rizzi (1997) investigate the canceling of the that-trace effect by adjuncts (Browning calles it 'the adverb effect'). However they reason as if all adjunct types would show the effect. They do not discuss that certain adjuncts do not mitigate the ungrammaticality.

Browning and Rizzi share two crucial assumptions to explain examples like (56b). The first is that the complementizer that can not be endowed with Agr features to licence the trace of the subject. An empty complementizer, however, is supposed to be consistent with Agr. The second assumption is that, by the presence of the sentence initial adjunct, an additional functional layer is generated such that an empty complementizer becomes adjacent to the trace of the subject. In Rizzi's (1997) framework, (56b) roughly would get a structure like the following:

(56b)' $\mathrm{Who}_{1}$ do you think that [unfortunately $\left[\mathrm{F}^{\mathrm{i}}+\mathrm{Agr}_{1}\left[\mathrm{~F}^{\mathrm{j}}\right]\right]\left[\mathrm{t}_{1}{ }^{\prime} \mathrm{F}^{\mathrm{i}}+\mathrm{Agr}_{1}\left[\mathrm{t}_{1}\right.\right.$ made no reply $\left.]\right]$

The subject trace $t_{1}$ is licenced by the empty functional projection $F^{i}$ which is endowed with Agr features. These Agr features are licenced by the intermediate subject trace $t_{1}$ ' in the specifier position of $F^{i}$. How is $t_{1}{ }^{\prime}$ licenced? Rizzi (1997) assumes that in English the enriched functional head $\mathrm{F}^{\mathrm{i}}+\mathrm{Agr}$ can move to the higher functional head $\mathrm{F}^{\mathrm{j}}$. From there it can licence $t_{1}^{\prime}$.

As already mentioned, Rizzi (1997) and Browning (1996) do not consider adjuncts which do not show the adverb effect like the one in (56c). However Browning and Rizzi point out that preposed arguments do not mitigate the that-trace effect. Brownings approach to explain the difference between adjuncts showing the effect and preposed arguments depends on the assumption that the adjuncts are base generated in the sentence initial position whereas arguments are moved there.

The examples in (55) showed that in German the base position of a subject-oriented adjunct has to be c-commanded by the the subject at some level, whereas such a restriction does not hold for the other SADJs. If we assume the same difference for English we are able to explain the contrast between (56b) and (c). In (56b) unfortunately can be base generated in its surface position. In contrast, stupidly in (56c) has reached its position by movement because it has to be base generated below the subject. Therefore stupidly carries a movement index. We get the following structure, which is illformed:

$(56 \mathrm{c})^{\prime} * \ldots\left[\right.$ stupidly $_{2}\left[\mathrm{~F}^{\mathrm{i}}+\mathrm{Agr}_{1}\left[\mathrm{~F}_{2}^{\mathrm{j}}\right]\right]\left[\mathrm{t}_{1}{ }^{\prime} \mathrm{F}^{\mathrm{i}}+\mathrm{Agr}_{1}\left[\mathrm{t}_{1} \mathrm{t}_{2}\right.\right.$ made no reply $\left.]\right]$

By obligatory spec-head agreement, the index on stupidly is present on $\mathrm{F}^{\mathrm{j}}$. Therefore the head to head movement of $F^{i}+$ Agr to $F^{j}$, which would be necessary to licence $t_{1}{ }^{\prime}$, results in contradicting indices on $\mathrm{F}^{\mathrm{j}}$.

Our observations about subject-oriented adjuncts in English and German can be captured by the following contraint. Since it can be shown that in English subject-oriented 
adjuncts show the same sensitivity to surface structure like mental-attitude adjuncts, the condition (ii), which expresses the dependency on the highest argument, is the same as the condition in (47):

\section{(57) Subject-oriented adjuncts}

The base position of a subject-oriented adjunct

(i) is subject to the condition for SADJ in (9) and

(ii) is c-commanded by a highest ranked argument inside the extended projection of the main predicate. Semantically, a subject-oriented adjunct relates to the closest c-commanding highest ranked argument.

The approach to explain the difference in grammaticality between (56b) and (c) with the difference of base generation of the adjunct versus movement seems to be on the right track. This is supported by the following data:

(58) a. Who ${ }_{1}$ do you think that on Ben's birthday $t_{1}$ took it easy

b. Who ${ }_{1}$ do you think that for this reason $t_{1}$ was awarded a prize

c. ${ }^{*} \mathrm{Who}_{1}$ do you think that in Ben's office $\mathrm{t}_{1}$ lay on his desk

d. ${ }^{*} W_{h} o_{1}$ do you think that with Mary's computer $t_{1}$ began to write a book of poetry

e. ${ }^{*} \mathrm{Who}_{1}$ do you think that for Mary's brother $\mathrm{t}_{1}$ was given some old clothes

The adjuncts of $(58 \mathrm{a}, \mathrm{b})$ are event-external adjuncts and have to obey condition (31). The adjuncts in (58c-e) are event-internal adjuncts and have to obey (30). The former adjuncts can be base generated in sentence initial position, the latter ones are moved there. Thus we have the same situation as above. Base generated adjuncts mitigate the that-trace effect, moved adjuncts do not. The explanation for the differences in grammaticality in (58) is the same as for $(56 b)$ and (c).

The examples (33) in section 3 already illustrated the difference between sentence initial locative and temporal adjuncts in German, the former being marked and the latter unmarked. As it is now expected, we find the same difference between a subject-oriented adjunct and the other SADJs, the contrast being even sharper:

(59) a. ?Intelligenterweise hat Hans das Buch gelesen wisely has $H$. the book read

b. Glücklicherweise hat Hans das Buch gelesen fortunately has $H$. the book read

The adjunct in (59a) is not perfect in clause-initial position. According to (57) it is moved to this position. In contrast the sentence initial base generation of the SADJ in (59b) results in a fully grammatical structure.

The same kind of reasoning can explain the following data:

(60) a. Leider hat Peter oft gefehlt Unfortunately has Peter often be-absent

'Unfortunately Peter was often absent'

b. ?Oft hat Peter leider gefehlt

c. Oft hat Peter gefehlt

d. Sehr oft hat Peter leider gefehlt 
The SADJ in (60a) is base generated in its base position. The frequency adjunct in (60b) is moved to the prefield because its base position has to be c-commanded by the SADJ (cf. section 8). As discussed in section 8 a frequency adjunct can be an event external adjunct. Therefore in $(60 \mathrm{c})$ the frequency adjunct can be base generated in its surface position. (60d) is better than (b) as F. Moltmann observed, referred to by Cinque (1997). The reason is that in this case the informational prerequisite for movement to the prefield is fulfilled. The frequency adjunct, not being able to be a topic due to its nonreferentiality, is in focus in this example.

A SADJ in the prefield may not be associated with an embedded clause (Doherty (1985)):

(61) ${ }^{*}$ Leider $_{1}$ sagte Maria daß $\mathrm{t}_{1}$ Otto das Spiel verloren hat Unfortunately said $M$. that $O$. the game lost has

A SADJ is neutral with respect to information structure. It can not be a topic. Rather it constitutes the borderline between the topics and the comment (cf. Frey (2000)). Furthermore it can not be focused. Therefore informational requirements on movement to the prefield can not be met by a SADJ.

\section{Manner Adjuncts}

Many authors assume that manner adjuncts are positioned higher than the arguments or at least higher than the internal arguments (e.g. Ernst (to appear) for English and French, Cinque (1997) for Italian, Eckardt (1996) for German). Our tests for German however do not confirm this assumption:

(62) a. Peter will jetzt was konzentriert lesen Peter will now something carefully read

b. Peter hat den Artikel sorgFÄLTIG geLEsen(wide focus possible)

$(62 \mathrm{a}, \mathrm{b})$ show that the manner adjunct is c-commanded by the base position of the object. The wh-indefinite object in (62a) can not be scrambled. As for (62b), compare this sentence with a sentence in which a locative adjunct is adjacent to the main verb:

(63) Peter hat den Artikel $_{1}$ im GARten $t_{1}$ geLEsen (no wide focus possible) Peter has the article in the garden read

As we have seen in section 3 the base position of the object is below a locative adjunct. Therefore there is a trace of the scrambled object between the locative and the main verb in (63). It is this trace that disallows a wide focus reading of (63). The fact that (62b) has a wide focus reading shows that there is no movement trace of the object between the manner adjunct and the verb.

Scope facts also show that manner adjuncts are generated below the object:

(64) a. Er HAT mindestens eine Kollegin auf jede Art und Weise umworben (only: $\exists \forall$ ) He has at least one colleague in every way courted

b. Er HAT auf mindestens eine Art und Weise fast jede Kollegin umworben ( $\exists \forall$ or $\forall \exists$ ) He has in at least one way nearly every colleague courted 
Thus our tests indicate that manner adjuncts should be generated next to the base position of the main predicate.

However proponents of the view that manner adjuncts are generated at least higher than the objects could point to examples like the following:

(65) a. Otto hat heute heftig einen Kollegen beschimpft

$O$. has today strongly a colleague insulted

b. Sie hat heute wunderbar Sonaten gespielt

She has today wonderfully sonatas played

In (65) the manner adjuncts occur naturally in front of the objects. Furthermore it is unlikely that the adjuncts are scrambled to this position because manner adjuncts of this form do not like to be scrambled ${ }^{11}$.

So it seems that examples like (62) on the one hand and (65) on the other constitute contradictory evidence. However in Frey \& Pittner (1998) we argue that the examples in (65) do not illustrate the general case but are due to a special phenomenon. Consider the following sentences:

(66) a. ??Otto hat heute heftig viele Kollegen beschimpft

$O$. has today strongly many colleagues insulted

b. *Da Otto grenzenlos eine Kollegin bewundert because $O$. without limits a colleague admires

In (66a) the object of (65a) is replaced by a quantified NP. In (66b) the object is not a patient as in the examples in (65) but a stimulus.

Analyzing phenomena unrelated to adjuncts, Jacobs (1993) comes to the conclusion that in German it is possible to integrate an object into a complex predicate under certain circumstances. Among the prerequisites for integration, according to Jacobs, are that the object has the thematic role of a patient and that it is not quantified. The examples in (66) do not fulfil these prerequisites. These objects therefore can not be integrated.

Based on this observation Frey \& Pittner (1998) argue that cases like (65) are compatible with the claim that manner adjuncts are generated next to the predicate. The objects of these examples are part of the predicate due to integration. That objects occuring after a manner adjunct have a special status is indicated by another fact. According to Haiden (1996) they are not fully referentially transparent. This can be illustrated as follows:

(67) a. ??Hans hat heute heftig Kollegen beschimpft; ich wüßte aber gerne welche H. has today strongly colleagues insulted; I'd like to know which ones

b. Hans hat heute Kollegen heftig beschimpft; ich wüßte aber gerne welche

Only the bare plural in front of the manner adjunct is accessible in a sluicing construction.

So there is evidence that the order shown in (62) is the basic serialization pattern of an object and a manner adjunct. Why then is it so often assumed that manner adjuncts are gene-

11 Compare:

(i) ??Otto hat heftig heute einen Kollegen beschimpft

$O$. has stronly today a colleague insulted

Note however that PP manner adjuncts may be scrambled:

(ii) Otto hat auf seine heftige Art heute einen Kollegen beschimpft

$O$. has in his vehement way today a colleague insulted 
rated above the arguments? One reason might be the alleged integrity of the theta domain. Many syntacticians assume that there is a certain domain of pure theta assignment in which no adjunct can appear. However we can also find in English examples for which it is hard to maintain that manner adjuncts are generated outside of the theta domain:

(68) John has spoken (nicely) to his mother (nicely) about her letter

It is possible to have a manner adjunct between the verb and a prepositional object. The crucial observation of Costa (1998) is that these PPs are not extraposed:

(69) What ${ }_{1}$ has John spoken to his mother nicely about $t_{1}$

The fact that a prepositional object following a manner adjunct does not show freezing effects for movement is a strong argument that it is in its base position. Note the contrast to the following example, which shows that the PP is extraposed (cf. section 3):

(70) *What 1 has John spoken to his mother yesterday about $t_{t}$

Examples like (68) suggest that in English the same constraint for manner adjuncts might be operative as in German. In section 3 we already exploited the binary right branching structure of English. This property will also explain the distribution of the adjuncts in (68). In the following structure, the traces left by verb movement inside $\mathrm{vP}$ are indicated ${ }^{12}$ :

$(68)^{\prime}$ a. $J_{o h n}$ has $\left[{ }_{v P} t_{2} \operatorname{spoken}_{1}\left[v P\right.\right.$ to his mother [ $v^{\prime} t_{1}{ }^{\prime}\left[v P\right.$ nicely $\left[v^{\prime} t_{1}\right.$ about her letter]]]]]

b. John ${ }_{2}$ has [ ${ }_{v P} t_{2}$ spoken $_{1}$ [vP nicely [ $v^{\prime} t_{1}^{\prime}$ [vP to his mother $\left[v^{\prime} t_{1}\right.$ about her letter]]]]]

In both structures the manner adjunct immediately c-commands a trace of the predicate. Note that all the verb positions in (68)' are involved in the licencing of arguments. Therefore they may all count as 'base positions' of the verb.

Given structures like (68)' we expect that manner adjuncts which are PPs should be possible in these positions. This expectation is confirmed:

(71) What has John spoken (with great care) to his mother (with great care) about

We can now formulate the constraint for manner adjuncts, which is supposed to apply in English and in German:

(72) Process-related adjuncts (e.g. manner adjuncts)

The base position of a process-related adjunct minimally c-commands a base of the main predicate.

(72) allows to explain the following contrast between English and German:

(73) a. Today John worried greatly about every girlfriend

b. ??Hans hat sich heute maßlos über jede Freundin geärgert

$H$. has refl. today extremely about every girlfriend get-annoyed

c. Hans hat sich heute über jede Freundin maßlos geärgert

12 With regard to the spec position of the adjuncts, the remark formulated in footnote 10 applies here too. 
The manner adjunct in (73a) is licenced because it minimally c-commands the trace of the verb. In (73b) however the adjunct does not minimally c-command the predicate. The manner adjunct has been moved and therefore the sentence is not fully grammatical.

Let us now look at another possible position for a manner adjunct in English. It is at the end of the clause. Because of the binary right branching structure of the English clause it is sister to a trace of the verb (cf. Larson (1988)):

(74) a. John has talked to his mother nicely

b. John has [talked ${ }_{1}$ to his mother [ $\mathrm{t}_{1}$ nicely]]

The adjunct satisfies condition (72). In contrast the following occurrences of a manner adjunct do not fulfil (72) $)^{13}$ :

(75) (*Nicely) John (*nicely) will (*nicely) have spoken to his mother about her letter

The reason is that the adjuncts in (75) do not minimally c-command the main predicate.

There is one occurrence left of items which are usually classified as manner adjuncts. This is the position directly in front of the main predicate:

(76) John will carefully study her letter

However it is important to note that carefully in this example is not a pure manner adjunct. As Cinque (1997) notes, a sentence like the following does not contain any contradiction:

(77) John has been cleverly talking about the problem stupidly

This is interesting because cleverly in (77) is not understood as a sentence adjunct, i.e. the situation is not evaluated by the speaker. In German it can be even seen morphologicaly that the corresponding element is not a SADJ:

(78) Hans hat geschickt die Fragen dumm beantwortet

$H$. has skillfully the questions stupidly answered

The SADJ would have the ending -weise (cf. geschickterweise).

Not all adjuncts which can appear as manner adjuncts postverbally may occur preverbally:

(79) a. John handled the situation terribly

b. *John terribly handled the situation

c. He played the sonata beautifully

d. *He beautifully played the sonata

e. He has danced with Mary marvellously

f. *He has marvellously danced with Mary

As Blight (1997) notes, these adjuncts can, however, occur in front of a main verb in the passive voice:

13 The star on the occurrence at the sentence initial position is meant to refer to a base generated and unmarked occurrence. It is possible to move a manner adjunct to this position. 
(80) a. The sonata was beautifully played

b. The situation was terribly handled by John

Blight argues that only active verbs move to $v$, passive verbs stay in VP. Therefore the structural position of the preverbal adjuncts in (79) is different from the position of the adjuncts in (80). Thus we have to understand what makes it possible for some of the manner adjuncts to appear in a position which is not a position for manner adjuncts in general.

Bartsch (1972) makes a distinction between manner adjuncts which might be of importance here. She notes that only some allow a paraphrase in which they are not directly predicated of the process but only via a predication on the subject. Consider the following sentences:

(81) a. He will work on the project carefully

b. He will work on the project and in doing that he will be careful

c. He will play the sonata beautifully

d. He will play the sonata and in doing that he will be beautiful

(81a) with carefully might be paraphrased as (81b). In contrast beautifully does not allow such a paraphrase. (81c) and (d) do not have the same meaning. If we check the adjuncts in (79) we see that they all do not allow such a paraphrase. However the manner adjuncts which are possible in front of an active verb do allow Bartsch's paraphrase.

In (81b) careful does not characterize the process. Rather it is used to characterize the subject in relation to the whole action described by the sentence. Seen in this perspective, it makes sense that only manner adjuncts which allow Bartsch's paraphrase may appear preverbally. In this position they are c-commanding $v \mathrm{P}$. Furthermore they are c-commanded by a position of the subject. The structural condition the elements fulfil in this position, is the same as the one for mental-attitude adjuncts.

It is clear that manner adjuncts which do not allow Bartsch's paraphase, i.e. adjuncts which allow only the strict manner reading, can not appear preverbally. The condition in (72) can not be fulfilled in this position because the trace of the subject intervenes between the adjunct and the predicate.

Let us finally ask the question whether there are adjuncts in addition to manner adjuncts which are subject to condition (72)? Domain adjuncts like politically or linguistically are sometimes grouped with manner adjuncts, e.g. by Ernst (to appear). Cinque (1997) however classifies them as SADJ. The following data confirm Ernst's classification. They show that domain adjuncts obey condition (72). In German they are base generated below the subject and below the object:

(82) Heute hat hier wer wen finanziell ruiniert

Today has here someone someone financially ruined

In English we find the following data:

(83) Paul (*politically) will (??politically) have (??politically) been (politically) ruined (politically)

(83) is a passive construction. The domain adjunct has the same distribution as a manner adjunct. With an active verb and an agentive subject a domain adjunct is not possible preverbally: 
In this construction the verb moves to $v$, so this is what we expect if (72) holds for domain adjuncts.

For another adjunct type which fulfils condition (72) the reader is referred to Maienborn (2000). Maienborn develops an analysis of what she calles 'internal locative modifiers' illustrated by the following example:

(85) Der Koch hat das Hähnchen in einer Marihuana-Tunke zubereitet The cook has the chicken in a Marihuana sauce prepared

Maienborn does not only give a semantic analysis of this kind of modifiers but she also gives evidence that they fulfil a condition like (72).

\section{Frequency adjuncts}

The last type of adjuncts I would like to consider are frequency adjuncts. Frequency adjuncts however do not constitute a further adjunct class with its own distributional requirements. Rather frequency adjuncts belong to different adjunct classes already discussed.

In the following German examples the frequency adjuncts occur in three different positions. All examples are unambiguous:

(86) a. DASS Max fast alle Anwesenden oft beleidigte - unambiguous that Max nearly all persons present often offended

b. DASS Max oft fast alle Anwesenden beleidigte - unambiguous

c. DASS oft an mindestens einem Tag der Strom ausfällt - unambiguous that often on at least one day the current fails

This shows that in these examples the frequency adjuncts and the quantified phrases are base generated in their surface positions. Thus a frequency adjunct may be base generated next to the predicate, between subject and object or higher than the arguments.

It makes perfect sense to have several frequency adjuncts in one clause:

(87) weil häufig wer mehrmals Schrauben zu oft anzog

because often someone several times screws too often tightened

The sentence is understood in such a way that the frequency adjuncts quantify over different semantic objects: over the event, over a partial event and over the process described by the predicate. Data like (86) and (87) therefore suggest that frequency adjuncts may belong to the class of event-related adjuncts, to the class of event-internal adjuncts (type I) and to the class of process-related adjuncts.

The findings in German are confirmed by English data. Here too frequency adjuncts have the broadest distribution of all adjuncts types considered in this paper:

(88) (Frequently) she (frequently) has (frequently) been (frequently) talking (frequently) to Mary (frequently)

This suggests that also in English frequency adjuncts belong to different adjunct classes.

Let us finally consider the following examples discussed by Cinque (1997): 
(89) a. John intentionally knocked on the door twice

b. John twice knocked on the door intentionally

Cinque (1997) notes that (89a) is ambiguous: intentionally can have scope over twice or twice can have scope over intentionally. In contrast (89b) has only one reading: twice has scope over intentionally.

With our conditions for the different adjunct classes we can explain the observed distribution of readings. Adjuncts occuring at the right periphery of an English clause may be process related, event-internal or event-external, $\mathrm{cf}$. the next section. A frequency adjunct like twice belongs to these different adjunct classes. If in (89a) twice is analysed as a processrelated adjunct it is in the scope of the event-internal adjunct intentionally, because eventinternal adjuncts c-command process-related adjuncts. If it is analysed as event-external, it has scope over intentionally because event-external adjuncts c-command event-internal ones. In (89b) however twice can only be an event-external adjunct. Therefore this sentence has only the reading with twice having scope over intentionally.

\section{Adjuncts at the right end of the sentence}

The ordering of adjuncts at the right periphery of an English clause mirrors the ordering of adjuncts in the middle field of a German clause or to the left of the predicate in English. The following sentence shows the unmarked order of an instrumental, a locative and a temporal adjunct, the position of the manner adjunct being expected (cf. section 6):

(90) He worked carcfully with his sheares in the garden the whole morning

Furthermore, if the adjuncts at the right end are scope sensitive, it can be shown that an adjunct more to the right has scope over an adjunct to its left. The ordering preferences and the scope relations would find an easy explanation if the adjuncts at the right periphery (except manner) would be right adjoined to the different projections. However, as is well known, binding facts give evidence that the adjuncts at the right are c-commanded by the arguments (cf. e.g. Rosengren (2000)). This makes an analysis using right adjunction highly unplausible.

As Pittner (1999) observes, we find the same mirror image of the order with extraposed sentential adjuncts in German. The judgements are even sharper:

(91) a. Er hat sich ein Lager gebaut wo er gerade war als es dunkel wurde

He has himself a camp built where he just was when it dark grew

b. ?Er hat sich ein Lager gebaut als es dunkel wurde wo er gerade war

As for English it can be shown that extraposed adjuncts are in the c-command domain of the arguments in the middle field:

(92) Sie hat jeden ${ }_{1}$ beschenkt als er 1 Abschied feierte

She has everyone given-a-present when he farewell-party had

'She has given a present to everyone when he had his farewell party'

There is a remark about how to analyse the phrases at the right end of the clause in chapt. 4 of Chomsky (1995): "if a shell structure is relevant at all, the additional phrases might be supported by empty heads below the main verb ...". This proposal is taken up by Haider (1999): "The empty head in the extraposition subtree is just a structural licencer. In other 
words, it guarantees endocentricity plus binary branching, and must be structurally licensed by a lexical head itself." Rosengren (2000) pursues a similiar line of reasoning.

All sentence final adjuncts except process-related ones belong to the extraposition field with its empty heads in English. Sentence final process-related adjuncts are part of the core sentence structure. In Frey \& Pittner (1999) we added the following proposal to the idea of the extraposition field. The extraposition field constitutes a pure structural environment. In order to become interpretable the phrases appearing in this field have to be connected to abstract markers in the interpreted domain of the sentence. The abstract marker corresponding to a given adjunct has to fullfil the c-command conditions which hold for the class the adjunct belongs to. Let us assume that in the unmarked case the paths connecting the phrases in the extraposition field with the associated markers in the interpretation domain do not cross. Then the order of the sentence final elements will mirror the order of the elements occuring in the core sentence structure.

SADJ can not appear sentence finally in English (without comma intonation). All 'lower' adjuncts, i.e. all adjuncts which have to be c-commanded by a SADJ according to our conditions, may occur at the end of the sentence. Compare for example a mental-attitude adjunct with a SADJ:

(93) a. Mark rode a bicycle on the day of the transit strike willingly

b. *Mark was riding a bicycle on the day of the transit strike luckily

Note that even frame adjuncts can appear in this position:

People eat in fast food restaurants in America

I can not offer an explanation for the restriction for SADJs. SADJs are the only adjuncts which, according to our constraints, have to c-command the finite verb. Therefore I stipulate that this restriction can not be fulfilled by elements in the extraposition field. This means that the corresponding abstract markers are not able to enter a structural relation with finiteness. The reason for this might be that elements in the extraposition field, which is licensed by a lexical head and does not contain any functional structure, can only interact with lexical material. They can not interact with the encoding of functional information like finiteness.

The abstract markers of the other adjuncts interact with lexical material. Note that the requirement on event-internal adjuncts, type I, can now be fulfilled by the associated abstract marker. With regard to (40)/(41) of section 3 , it was observed that e.g. a locative adjunct itself can not fulfil the requirements put on it inside the verbal projection, the reason being that the verb moves to a position in which it is next to the base position of the subject. An abstract marker between the subject's base and the verb however does not impair their structural closeness. Therefore the base position for a locative adjunct in English is at the right periphery. The only other position in which it may occur in an English clause is sentence initially. This is a position which it has reached by movement.

\section{A note on the 'scopal' approach}

The proposal presented here is between an approach like Cinque (1997) with only one possible position for a given adjunct and an approach like Ernst (to appear) or Haider (1999) according to which syntax proper does not constrain the distribution of adjuncts except to exclude certain positions for adjuncts in general. Instead semantics is supposed to regulate the distribution of adjuncts. Because critical discussions of Cinque's approach can be found in the 
literature (e.g. Ernst (to appear), Haider (1999)) I only want to make some remarks about the second approach.

According to Haider or Ernst, syntax does not state special conditions for the different adjunct classes. The reason why there are certain serialization patterns lies in the mapping procedure to semantics. Preverbal adjuncts which relate to a more specified semantic domain have to c-command preverbal adjuncts which relate to a less specified domain. Haider (1999) differentiates only three semantic domains:

$$
\text { proposition } \subset \text { event } \subset \text { process } / \text { state }
$$

Haider (1999) and Ernst (to appear) relate for example all the adjuncts we categorized either as event-related adjuncts or event-internal adjuncts in section 3 to the event variable introduced into the structure. However if the members of these two classes are treated alike by the syntactic component, all the differences discussed in section 3 can not be explained. To take just three arbitrary examples: Why should there be any difference between sentences like $(20 a)$ and $(d)$, between $(34 a, b)$ and $(c, d)$ or between the examples in (36)? These data are all the more problematic for the 'scopal' approach as only one of the adjuncts under consideration occurs per clause. Haider (1999) expects only certain scopal restrictions between adjuncts. That the base positions of adjuncts should be sensitive to the position of arguments is not expected.

It might seem that an approach which wants to explain the distribution of adjuncts solely by their semantic type needs much more fine grained semantic distinctions than the ones in (95). However the introduction of a finer semantic ontology can not solve the problem. In this case according to the 'scopal' approach it should not be possible that members of the different adjunct classes could easily permute. But this is just what we have seen in the examples in (19).

There are more data which remain hard to explain also after the introduction of finer semantic distinctions. Let's take for example the different behaviour of mental-attitude adjuncts in English and German discussed in section 4. Our explanation crucially relies on a structural condition holding for the adjunct with respect to the most prominent argument and on the different sentence structures in the two languages. Another example is subject-oriented adjuncts. Although they belong to the SADJs, they have to obey the extra structural condition that their base is c-commanded by a derived position of the subject. This extra structural condition was crucial for the explanation of the difference between (56b) and (c).

The approaches of Haider and Ernst necessarily have the consequence that adjuncts do not scramble. All positions in which a given adjunct can appear in the German middle field are base generated positions. However this consequence does not seem to be right:

(96) a. da Otto auf mindestens eine Weise an nahezu jedem Tag Maria umworben hat because $O$. in at least one way on nearly every day $M$. courted has

b da Otto an mindestens einem Tag auf fast jede Weise Maria umworben hat because $O$. on at least one day in nearly every way $M$. courted has (only: $\exists \forall$ )

c. Klara hat mit mindestens einem Computer an fast jedem Abend gearbeitet $K$. has with at least one computer on nearly every evening worked

d. Klara hat an mindestens einem Abend mit fast jedem Computer gearbeitet (only: $\exists \forall$ ) $K$. has on at least one evening with nearly every computer worked

If the adjuncts in (96) are all base generated there should be no differences in scope possibilities. If however adjuncts have certain base positions and if they can be scrambled we expect differences like the ones observed in (96). Note that our conditions for the possible base posi- 
tions of the different adjunct classes together with the scope principle in (3) predict the interpretations of the sentences in (96) correctly.

\section{Summary}

I have argued that the syntactic component of the grammar regulates the distribution of adjuncts. The ordering constraints can not be reduced to semantic scope conditions. Syntax, however, does not prescribe exactly one base position for a given adjunct. Rather an adjunct can be base generated in different positions as long as the c-command requirements are met which the adjunct has to fulfil with regard to the arguments and to other adjuncts occurring in the clause. We have distinguished five major classes:

(97) (i) SADJs (e.g. fortunately, probably): The base position of a SADJ c-commands the finite verbal form, the base positions of the arguments and the base positions of the elements of the classes (ii)-(v).

(ii) Frame adjuncts (e.g. in the Middle Ages):

The base position of a frame adjunct c-commands the base positions of the arguments and the base positions of the elements of the classes (iii)-(v).

(iii) Event-related adjuncts (e.g. temporal, causal): The base position of an event-related adjunct c-commands the base positions of the arguments and the base positions of the elements of the classes (iv)-(v).

(iv) Event-internal adjuncts

Type I: (e.g. locatives, instrumentals): Their base positions are minimally ccommanded by the base position of the highest argument.

Type II: (e.g. mental attitude adjuncts): Their base positions are c-commanded by a highest ranked argument in the extendend projection of the lexical verb.

(v) Process-related adjuncts (e.g. manner): The base position of a process-related adjunct minimally c-commands a base of the lexical verb.

The syntactic component does not regulate the distribution of members of the same adjunct class with respect to each other. If there are ordering contraints between members of the same class they are not syntactically encoded but are of a pure semantic nature.

In addition to the base serialization generated by (97) there are other orders possible between members of the different classes. These orders are derived by movement.

\section{References}

Bartsch, R. (1972): Adverbialsemantik. Die Konstitution logisch-semantischer Repräsentationen von Adverbialkonstruktionen. Frankfurt: Athenäum.

Blight, R. (1997): Verb Movement and the Distribution of Copular be. In: K. Kusumoto (ed.): Proceedings of NELS 27, GLSA, Umass/Amherst, 49-63.

Browning, M.A. (1996): CP Recursion and that-t Effects. In: Linguistic Inquiry 27, 237-255.

Chafe, W. (1976): Givenness, Contrastiveness, Definiteness, Subjects, Topics, and Point of View. In: C.N. Li (ed.): Subject and Topic. New York: Academic Press.

Chomsky, Noam (1981): Lectures on Government and Binding. Dordrecht: Foris.

- (1995): The Minimalist Program. Cambridge/Mass.: MIT Press.

Cinque, G. (1997): Adverbs and Functional Heads. A Cross-Linguistic Perspective. Oxford: Oxford University Press. 
Costa, J. (1998): Word Order Variation: A Constraint-Based Approach. The Hague: Holland Academic Graphics.

Diesing, M. (1992): Indefinites. Cambridge/Mass.: MIT Press.

Doherty, M. (1985): Epistemische Bedeutung. Berlin: Akademie Verlag (studia grammatica XXIII).

Eckardt, R. (1996): Events, Adverbs and Other Things. Dissertation University of Stuttgart.

Ernst, Th. (1991): On the Scope Principle. In: Linguistic Inquiry 22, 750-756.

- $\quad$ (to appear): The Syntax of Adjuncts. Cambridge University Press.

Frey, W. (1993): Syntaktische Bedingungen für die semantische Interpretation. Berlin: Akademie Verlag (studia grammatica 35).

- (2000): Über die syntaktische Position der Satztopiks im Deutschen. Ms., ZAS Berlin.

Frey, W./K. Pittner (1998): Zur Positionierung der Adjunkte im deutschen Mittelfeld. In: Linguistische Berichte $176,489-534$.

- (1999): Adverbialpositionen im deutsch-englischen Vergleich. In: M. Doherty (ed.): Sprachspezifische Aspekte der Informationsverteilung. Berlin: Akademie Verlag (studia grammatica 47), 14-40.

Grundzüge einer deutschen Grammatik (1981): Von einem Autorenkollektiv unter der Leitung von Karl-Erich Heidolph, Walter Flämig und Wolfgang Motsch. Berlin: Akademie-Verlag.

Haiden, M. (1996): The Aspect of Short Scrambling. In: Wiener Linguistische Gazette, 57-59, Institut für Sprachwissenschaft Wien, 121-145.

Haider, H. (1993): Deutsche Syntax - Generativ. Tübingen: Narr.

- (1999): Adverb Placement - Convergence of Structure and Licensing. Ms., Univ. of Salzburg (in press: Theoretical Linguistics).

Hetland, J. (1992): Satzadverbien im Fokus. Tübingen: Narr.

Höhle, T. (1982): Explikation für "normale Betonung" und "normale Wortstellung". In: W. Abraham (ed.): Satzglieder im Deutschen. Tübingen: Narr, 75-153.

de Hoop, H. (1992): Case and Configurationality. Ph. D. Dissertation, Univ. Groningen.

Jacobs, J (1993): Integration. In: M. Reis (ed.): Wortstellung und Informationsstruktur. Tübingen: Niemeyer, 63116.

(1999): The Dimensions of Topic - Comment. Ms., Univ. of Wuppertal.

Kayne, R. (1994): The Antisymmetry of Syntax. Cambridge/Mass.: MIT Press.

Laenzlinger, C. (1998): Comparative Studies in Word Order Variation. Amsterdam: Benjamins.

Larson, R. (1988): On the Double Object Construction. In: Linguistic Inquiry 19, 335-391.

Maienborn, C. (1998): The Grammar and Pragmatics of Locative Modifiers. Ms., Humboldt University Berlin.

- (2000): Modification and Underspecification: A Free Variable Account of Locative Modifiers. In this volume.

Neeleman, A. (1994): Scrambling as a D-structure Phenomenon. In: N. Corver \& H.v. Riemsdijk (eds.): Studies on Scrambling: Movement and Non-Movement Approaches to Free Word-Order Phenomena. Berlin: Mouton de Gruyter, 387-429.

Pittner, K. (1999): Adverbiale im Deutschen. Untersuchungen zu ihrer Stellung und Interpretation. Tübingen: Stauffenburg.

Rizzi, L. (1997): The Fine Structure of the Left Periphery. In: L. Haegeman (ed.): Elements of Grammar. Handbook in Generative Syntax. Dordrecht: Kluwer, 281-337.

Roberts, I. (1987): The Representation of Implicit and Dethematized Subjects. Dordrecht: Foris.

Rosengren, I. (2000): Rethinking the Adjunct. In this volume.

Zwart, C.J.W. (1993): Dutch Syntax: A Minimalist Approach. Ph. D. thesis, University of Groningen. 